\title{
AN ANALYSIS OF CULTURAL VOCABULARY IN ELT TEXTBOOKS
}

\author{
Andrés Canga Alonso y Daniela Cifone Ponte, Universidad de La Rioja ${ }^{1}$ \\ Email: andres.canga@unirioja.es, danielacifo@hotmail.com
}

\begin{abstract}
This paper analyses the cultural vocabulary of two ELT textbooks from two different levels of Spanish education, i.e. $4^{\text {th }}$ grade of secondary education and $2^{\text {nd }}$ baccalaureate. The words obtained were extracted from the vocabulary and reading activities and classified by means of a list of cultural categories (Byram \& Morgan, 1994; Common European Framework of Reference, 2001). Our findings reveal that the total number of words related to culture encountered in both textbooks is not balanced. Besides, geographical locations and famous or influent characters are highlighted, leaving aside controversial topics. Finally, the ELT textbooks analysed tend to focus on the target culture.
\end{abstract}

Keywords: Vocabulary, ELT textbooks, source culture, target culture, international culture.

Título en español: "Un análisis del vocabulario cultural presente en los libros de texto de inglés como lengua extranjera".

Resumen: Este trabajo analiza los resultados obtenidos en el análisis del vocabulario con contenido cultural de dos libros de texto de inglés utilizados en dos niveles distintos del sistema educativo español: $4^{\circ}$ de Educación Secundaria Obligatoria y $2^{\circ}$ de bachillerato. Las palabras fueron extraídas de las actividades de compresión escrita y vocabulario y clasificadas con la ayuda de dos listas de categorías culturales (Byram y Morgan, 1994; MCER, 2001). Los resultados revelan que el número de palabras con contenido cultural de ambos textos no están equilibradas. Además, se concede mucha importancia a la localización geográfica y los personajes importantes dejando a un lado temas controvertidos. Por último, los libros analizados tienden a centrarse en la cultura meta.

Palabras clave: Vocabulario, libros de textos de inglés como lengua extranjera, cultura origen, cultura meta, cultura internacional.

\section{INTRODUCTION}

The notion of Intercultural Competence (IC) regarding foreign language teaching (FLT) started to develop some decades ago (Risager, 1990; Byram \& Esarte-Sarries, 1991; Kramsch, 1993; Byram, 1997). However, it was not until recent years when it gained

1 Date of reception: 30 June 2015

Date of acceptance: $s$ 
ground among researchers and textbook publishers. IC is a necessary skill for students' success in interactions with members of different cultures to raise self-awareness of one's own culture and cultural values (Sercu, 2005; Deardorff, 2006; Vrbová, 2006; Wu, 2010; Paricio Tato, 2014).

On the other hand, vocabulary has achieved a great influence in FLT due to its essential role in the development of language proficiency (Verhoeven, 1990; Jiménez, García \& Pearson, 1996; Nagy, 1997; Hu \& Nation, 2000). What is more, vocabulary and culture are extremely linked as words and expressions may vary their meaning and implications in different languages since they are conditioned by communities' beliefs and ideas (Williams, 1976; Wierzbicka, 1997). Nevertheless, there is a scarcity of research which explores culturally-related vocabulary in ELT textbooks. Hence, this study aims to explore how the cultural component regarding vocabulary is represented and addressed in two textbooks implemented in the last year of secondary school and baccalaureate from a secondary school located in the north of Spain. We are interested in examining if culturally-related vocabulary is considered equally important at different levels of education, and how culturally related words are treated through teaching activities. We will also pay close attention to the ways target, source and international cultures are represented along the books. Hence, we review studies dealing with culture, Intercultural Competence (IC) and cultural content in ELT textbooks. Report of the study conducted with its methodology, main results found and interpretation of the same follows. We conclude pointing out some lines for further research trying to overcome the main limitations of the present study.

\section{THEORETICAL FRAMEWORK}

\subsection{Culture and Intercultural Communication (IC) in ELT textbooks}

Culture is what gives shape and define all human beings. It includes accepting a series of assumptions and practices which are inside a specific cultural context (Liddicoat and Scarino, 2013). The notion of culture in FLT implies target and source culture (Risager, 1990; Kramsch, 1993; Byram, 1997). Source culture refers to students' native culture, whereas target culture is that culture or cultures involved in the study of a language. In more recent times, a third subtype has been added to this classification: international culture (Cortazzi and Jin, 1999; Tas, 2010). This later type of culture includes those cultures which are neither the native culture nor the culture which is the object of study.

The term culture formed the basis for Intercultural Communication (IC). Byram and Fleming define IC as the ability that people who participate in different cultural contexts have to "reconcile or mediate between different modes present" (1998: 12). As can be noticed, culture and IC are interwoven, but we can differentiate between both concepts since the cultural perspective focuses its attention on a culture which is external to the learner while the intercultural integrates learners' own culture in the process of learning (Liddicoat and Scarino, 2013).

Foreign language textbooks are designed to form students in a concrete language. But what is a language but the representation of a culture? As Byram and Risager state "language contains culture; it carries its culture in it as it is a resource of cultural information of a 
concrete community" (1999: 147). This culture can cause breakdowns in communication among learners and native speakers (Kramsch, 1993). Hence, culture should receive proper treatment in language teaching not only by the teacher but also by the textbooks used in the classroom. Textbooks are not just a mere source of knowledge but the representation that students have of different societies and their respective values. For this reason, if used properly, textbooks should be considered as a potential tool to foster IC in the classroom.

The Common European Framework of Reference for Languages (CEFR) (2001) was compiled by the Council of Europe and serves as a common basis for the elaboration of textbooks. The CEFR insists on the idea that foreign language learners should acquire the socalled intercultural know-how skills (savoir-faire) which include social, living, vocational, professional and leisure skills. It also determines that students should acquire the ability to relate the culture of origin with the foreign culture to solve intercultural misunderstanding and distinguish stereotypes. Finally, this document also claims that communicative language competence should include the linguistic, sociolinguistic and pragmatic component. Regarding the sociolinguistic competence, it highlights that language communication within different cultures is affected by the sociolinguistic component. As a consequence, social conventions affecting both languages should be taught in FL courses.

Textbook researchers started gradually to pay more attention to ELT textbooks and several studies emphasized the importance of culture and context in the FLT as an essential part to foster L2 learning (Byram, 1989; Byram and Esarte-Sarries, 1991; Kramsch, 1993). What is more, it has been claimed that textbooks or any type of teaching material should be capable of giving information about the language and culture that is being learned (Sercu, 2005; Liddicoat and Scarino, 2013). Similarly, scholars have attempted to make a list of topics with cultural content that should be present in ELT textbooks (Risager, 1990; Byram and Morgan, 1994; CEFR, 2001; Sercu, 2005). These lists have had great influence on textbook research, which has become a crucial part in the development and improvement of teaching materials, paying close attention to the development of students' IC.

As far as the representation of different cultures in ELT textbooks is concerned, Kramsch (1993) stated that there should be a balance between the representation of the target and the source culture. Furthermore the UNESCO (Pingel, 2010) and the CEFR (2001) established that international understanding should be promoted through textbooks and, as a consequence, different cultures should be represented in textbooks in proportion. In other words, textbooks should include three types of culture: target culture, source culture and international cultures (Cortazzi and Jin, 1999; Tas, 2010). However, content analyses of English textbooks have proved that the representation of these three subtypes of culture is not balanced. There is a tendency to represent the target culture as predominant whereas the source culture and international cultures are scarcely introduced (Méndez García, 2000; Vrbová, 2006; Hamiloglu and Mendi, 2010; Yuen, 2011). As a result, the capacity that a student is supposed to acquire regarding the CEFR in order to assimilate and understand other cultures by comparing them to their own or to another is affected (Risager, 1990; Vrbová, 2006; Wu, 2010).

Some of these analyses have not only proved that the cultural component is insufficient and imbalanced but there is also a tendency to create stereotypes. The student is provided with some aspects of the target culture- which are mostly modified - and they accept them 
as true and do not attempt to question them. This can lead to the construction of negative or even positive stereotypes; neither of them is good since they create a preconceived image of the aforesaid culture (Méndez García, 2000; Siddiqie, 2011).

Having shown the importance given to the cultural component of ELT textbooks in different countries, we now move on to address the importance that vocabulary plays in ELT textbooks to foster IC.

\subsection{Vocabulary in ELT textbooks and its cultural component.}

Vocabulary knowledge is acknowledged to be of paramount importance to facilitate students' interaction in the foreign language. Thus, those learners with a limited vocabulary repertoire find more difficulties when reading and writing texts in the L2 (Verhoeven, 1990; Jiménez, García \& Pearson, 1996; Nagy, 1997; Hu and Nation, 2000).

As abovementioned, textbooks are the main tool a teacher has in language teaching; as a consequence, they are also the main vocabulary provider for students. For this reason, the selection of vocabulary and the activities which deal with vocabulary have become the main focus of scholars' attention (Jiménez Catalán and Mancebo Francisco, 2008; Criado, 2009; Criado and Sánchez, 2012).

Vocabulary is strongly linked to culture since words are different in each language not only in their form but in their meaning since they are affected significantly by the feelings, ideas and experiences that are shared by the community in which they occur (Williams, 1976; Wierzbicka, 1997; Bennett, Grossberg and Morris, 2005). In the same vein, the CEFR (2001) emphasizes that the cognitive organization of vocabulary and expressions is given by cultural features of those communities which the speaker has been in contact with. Moreover, the lexicon is a linguistic form where the influence of culture could be more noticeable and words can encode "culturally context conceptual systems" (Liddicoat and Scarino, 2013: 28). As words carry a great loading of meaning and connotations, their incorrect use or the lack of understanding or familiarity with the culture that surrounds them can lead to a misunderstanding in conversation and even provoke a breakdown in communication (Dimitrijevic, 1977).

Despite culture has been considered something inherent to language and its lexicon, little research has been conducted about culture-related vocabulary in ELT textbooks. To our knowledge only two studies based on the content analysis of the culture-related vocabulary in English textbooks have been published (Georgievska, 2000; Mahmood, Asghar and Hussain, 2012). Georgievska (2000) conducted an analysis of two textbooks: the first is the one used by secondary English students in Macedonia and it is locally-produced. The second tex tbook is the internationally used Headway Intermediate. In order to compare both books, she offers a general description of the treatment of the cultural component on those textbooks and then, she analyses them separately following Byram and Morgan's list (1994) and Risager's (1990) four category guide for the assessment of IC. Her findings prove that both books have gaps regarding socio-cultural vocabulary and when good opportunities of vocabulary related to culture are given, cultural connotations are not specified.

Mahmood, Asghar and Hussain (2012) also followed Byram and Morgan's model of exploration of cultural content in order to carry out a quantitative content analysis of an 
ELT textbook in Pakistan. The main aim of their analysis was to establish which culture is predominant in the textbook and if there were references to learners' native culture. The lack of information about the students' native culture was their main concern and they claimed that textbooks should represent just the target culture and avoid representing international cultures. To our knowledge, there is a lack of research concerning the intercultural component present in the vocabulary included in ELT textbooks used in Spanish secondary school. Hence, this paper attempts to answer the following research questions:

RQ1: Is the intercultural component present in the vocabulary contained the textbooks analysed in the present study?

RQ2: How are the different cultures (target, source and international) treated in those textbooks?

\section{METHODOLOGY}

The present study examines the cultural content of two textbooks used at two different levels in the same secondary school in La Rioja (Spain). The high school chosen is known because of its wide educational offer and its multicultural community of students. Regarding its educational offer, it is the only secondary school in the city which has an international baccalaureate. Likewise, it also provides the student with the option of joining the Official School of Languages program in order to gain access to an official certificate of English.

The first textbook analysed was English Alive 4 (Wetz, 2008). This textbook is designed for students from the last year of compulsory secondary education; the ages of students at this stage of education are around fifteen and sixteen. The second textbook is Aspire Upper-intermediate (Dummett, Benne \& Crossley. 2012). This textbook is addressed to students with a B1 level accredited and want to progress to B2. It is used in the ordinary curriculum of 2nd baccalaureate as well as in the Official School of Languages program by students around seventeen and eighteen years old.

In order to conduct the analysis of the vocabulary present in both textbooks, we made a classification by topics extracted from the textbooks in order to measure the number of words and their nature. For this reason, a list of cultural-related topics was created. Its design was based mainly on Byram and Morgan's (1994) and the CEFR's (2001) lists. This classification is relevant for this study as it will allow stating which cultural topics are the more recurrent and which of those are left aside by textbook publishers. As illustrated in table 1, the list includes twelve categories which represent different aspects of culture: 


\begin{tabular}{|l|l|}
\hline Everyday living & $\begin{array}{l}\text { Food, working, school, holidays, leisure activities, clothes, hou- } \\
\text { sing. }\end{array}$ \\
\hline Cultural heritage & $\begin{array}{l}\text { Famous monuments and people, literature, TV shows, movies, } \\
\text { music. }\end{array}$ \\
\hline National identity & $\begin{array}{l}\text { Languages, religions, nationality, history, humour, art and politics } \\
\text { from different cultures. }\end{array}$ \\
\hline Popular culture & $\begin{array}{l}\text { Rites, traditions, celebrations, festivals, social conventions, } \\
\text { dances, discos, religious observances and values, types of music, } \\
\text { among others. }\end{array}$ \\
\hline Society & $\begin{array}{l}\text { Living standards, classes, urban tribes, minorities, family structu- } \\
\text { res, regional cultures and subcultures. }\end{array}$ \\
\hline Geography & Countries, continents, cities, towns, streets. \\
\hline Stereotypes & Typical features attributed to certain cultures. \\
\hline Language & Borrowings, informal register, idioms, collocations. \\
\hline Worldwide issues & Political, economic, social and environmental issues. \\
\hline $\begin{array}{l}\text { Institutions and } \\
\text { organizations }\end{array}$ & Official institutions and organizations from different countries. \\
\hline Varieties & Words from other varieties of English. \\
\hline Social interaction & Greetings, apologies, politeness \\
\hline
\end{tabular}

Table 1. Topics for the classification of cultural words

The first topic, everyday living, was selected directly from the CEFR (2001). Nevertheless, it adds some aspects such as housing. Similarly, stereotypes, geography, cultural heritage and institutions and organizations were extracted directly from Byram and Morgan's (1994) list under no modification. The topic of national identity (Byram \& Morgan, 1994) encompasses two different categories: belief and behaviour. It covers aspects such as moral, religious beliefs, national history and historical events. Popular Culture is a mixture of some aspects covered by the category of belief and behaviour (Byram \& Morgan, 1994) as the routines of behaviour from daily life and, the category of ritual behaviour proposed by the CEFR (2001). Society is also treated as social identity and social groups (Byram \& Morgan, 1994) and as values, beliefs, attitudes and interpersonal relations (CEFR, 2001). As there was no area of study in Byram and Morgan's (1994) and the CEFR's (2001) lists regarding language, worldwide issues, varieties and social interaction it was considered necessary to add these three topics to the list since they represent a vital part of IC.

Data management and analysis was performed by classifying and obtaining quantities and percentages using Microsoft Excel ${ }^{\odot}$. Each classification was done separately in order 
to obtain different quantities and percentages from each textbook so we could proceed to compare them.

\section{RESULTS}

Regarding our first research question (RQ1: Is the intercultural component present in the vocabulary contained in the textbooks analysed in the present study?), three aspects will be considered: (1) the total number of culture words in each textbook; (2) those three categories with the highest results; (3) those three categories with the lowest results.

Words which imply cultural connotations were extracted from each unit of both textbooks and categorized in table 1 (see section 3 above). As shown in Table 2, the total number of words differs in the two textbooks under examination; Aspire Upper Intermediate (AUI) contains 405 more words than English Alive 4 (EA4). However, these data should be taken with caution since AUI contains two more units than EA4. Thus, we controlled for the number of pages both books contained and our findings surprisingly reveal little difference between the vocabulary input of each textbook. The quantity of words belonging to each topic and their percentages with respect to the total number of words are shown in the table below:

\begin{tabular}{|l|c|c|c|c|}
\cline { 2 - 5 } \multicolumn{1}{c|}{} & \multicolumn{2}{c|}{ English Alive 4 } & \multicolumn{2}{c|}{ Aspire Upper-intermediate } \\
\hline TOPICS & WORDS & PERCENTAGE & WORDS & PERCENTAGE \\
\hline Cultural Heritage & 66 & $17.05 \%$ & 59 & $7.45 \%$ \\
\hline Geography & 60 & $15.50 \%$ & 113 & $14.27 \%$ \\
\hline Popular Culture & 53 & $13.70 \%$ & 134 & $16.92 \%$ \\
\hline Language & 46 & $11.89 \%$ & 101 & $12.75 \%$ \\
\hline Everyday living & 46 & $11.89 \%$ & 106 & $13.38 \%$ \\
\hline National Identity & 23 & $5.94 \%$ & 40 & $5.05 \%$ \\
\hline Varieties & 17 & $4.39 \%$ & 0 & $0 \%$ \\
\hline Society & 13 & $3.36 \%$ & 36 & $4.55 \%$ \\
\hline Worldwide Issues & 7 & $1.81 \%$ & 36 & $4.55 \%$ \\
\hline $\begin{array}{l}\text { Institutions and } \\
\text { organizations }\end{array}$ & 7 & $1.81 \%$ & 13 & $1.64 \%$ \\
\hline Stereotypes & 6 & $1.55 \%$ & 3 & $0.38 \%$ \\
\hline Social interaction & 43 & $11.11 \%$ & 151 & $19.07 \%$ \\
\hline TOTAL & $\mathbf{3 8 7}$ & & $\mathbf{7 9 2}$ & \\
\hline
\end{tabular}

Table 2. Cultural words contained in both textbooks 
As illustrated in table 2, cultural heritage, geography and popular culture are those categories which have more representation in the vocabulary contained in EA4. As could be expected, the results indicate the existence of several categories which coincide in their position. Both textbooks share two of the three top categories and two of the three last categories. Thus, cultural heritage is the category with the highest results in EA4. A very high percentage of the words encountered are proper names of celebrities. There is limited reference to intellectuals or people who have influenced in the history of a specific culture (e.g. Mother Teresa of Calcutta or Leonardo Da Vinci, who only represent $12.12 \%$ of the words which included in this category). Similarly, $12.12 \%$ of these well-known people are neither American nor British. In addition, hardly any (3.03\%) of these characters are from a Spanish-speaking country. In AUI, only $8.34 \%$ of those words are related to celebrities or bands such as Jamie Oliver or Pink Floyd. Moreover, 56.67\% of the words related to cultural heritage refer to popular artists or writers such as Leonardo Da Vinci or Shakespeare. Unlike EA4, a higher percentage $(22.03 \%)$ of the celebrities is neither British nor American in AUI. Nevertheless, no mention was encountered to individuals from Spain or any Spanish-speaking country.

Geography obtains one of the highest results in both textbooks. In EA4, more than a third of the words from this category $(37.70 \%)$ refer to geographical locations situated in the UK, while $31.15 \%$ are not English-speaking countries or cities. Spanish-speaking countries only represent $3.33 \%$ of the total words. Regarding AUI, 50.44\% of the words about geography do not belong to English-speaking countries or cities. Furthermore, only $10.62 \%$ of these locations belong to the UK. Similarly to EA4, Spanish-speaking countries only represent $4.42 \%$ of total words. Therefore, it can be concluded that geography plays a vital role in ELT textbooks. However, there are clear differences between the results obtained from both textbooks. EA4 is addressed to younger students who may lack some geographical knowledge which older students are more likely to have. For this reason, more information was expected about locations (cities, towns, states, or streets) mentioned in the textbook. Nevertheless, despite being addressed to an older market, AUI does provide students with the exact location (country) of the city or town which is mentioned in a text. In the case of the latter, the geographical information given by the textbook seems to be conditioned by the idea that the student has the previous geographical knowledge of a specific location. As a result, those learners who do not know where a location is, may find problems to associate a given place with its location, therefore they may not gain this cultural fact due to their lack of background knowledge.

Popular culture, at least from a quantitative point of view, seems to be also a recurrent category. Nevertheless, analysing the content of this category, our results provide consistent evidence to state that it is treated differently in each textbook. AUI avoids covering controversial topics such as religion, since no data was found about this topic in the textbook and there is a notable preference to talk about festivals and traditional holidays instead. In contrast, $11.32 \%$ of EA4 words are related to religion, especially, Christianity. This difference between both textbooks can be partly explained by the fact that EA4 is specially published for Spanish students. The condition of Spain as a mainly catholic country could have contributed to the use of some words related to Catholicism and could account for the lack of references to other religious manifestations. 
Everyday living occupies the fourth position in EA4's ranking. Only $15.21 \%$ of the words classified in this category represent eating habits or typical dishes (fast food or fish and chips). $21.74 \%$ refer to activities, mostly sports or leisure activities which are not typical from a specific culture but common to almost all of them (e.g. football). In contrast, everyday living is one of the top three topics in AUI. Almost a third of the words classified (33.02\%) refers to professions such as dean or chef, while $27.36 \%$ deals with eating habits or typical dishes and common activities of a specific community e.g. kebabs, three-course meal or garage sales.

As for language, both textbooks present similar results. However, more than a half of the words classified in EA4 (56.52\%) are collocations (e.g. say a prayer or tell a lie) and only $6.52 \%$ are words from another language (e.g.cuaderno or slainte). $9.90 \%$ of the words categorized in AUI are not English (e.g. zongzi or ponti). In contrast, explicit treatment of expressions or idioms represents $17.82 \%$ of the total number of words (e.g. many hands make light work).

Society is presented similarly in both textbooks to represent a multiracial society. In the case of AUI, nearly half $(47.22 \%)$ of the words make reference to migration and some problems that migration could cause in society. Social classes only represent $25 \%$ of the words contained in this category as it is the case of middle class or slums. In the same vein, EA4 shows a high representation $(42.86 \%)$ of a multicultural society given by the topic of migrations (immigrant or multicultural) while just $14.29 \%$ of the words make reference to social classes, mostly upper classes (elite or snobs).

Varieties receive little treatment in both textbooks. Thus, AUI makes no reference to any variety of English regardless of British English, whereas EA4 refers to American and Irish English.

In the category of national identity, words related to nationalities prevail. There is little or no reference to specific religions, politics or history linked to a concrete country or culture. In EA4, 65.22\% of the words allude to nationalities or languages (Spanish or Urdu). Only $13.04 \%$ talks about historical events (e.g. suffragette movement) or ancient civilizations (e.g. Ancient Egypt). Likewise, 50\% of the words encountered in AUI refer to nationalities and languages (e.g. Mexicans or Greek). Moreover 22.5\% of the words mention historical events (e.g. The Saxons).

Correspondingly, the evidence we found in the number of terms about Worldwide Issues (1.81\% in EA4 and 4.55\% in AUI) concurs with the findings of Risager (1990), Vrborá (2006) and Wu (2010), with regard to the tendency to avoid socio-political and social problems in textbooks,. Both textbooks alluded to the same general problems - migrations, pollution and poverty - and none of these problems receives further treatment in any of the textbooks. Probably, the difference in the number of pages and the level of each textbook could account for these results. In our view, the avoidance of socio-political and social problems may be linked to the fact that these textbooks are addressed to a very young market that is not mature enough to face this kind of topics. At the same time not only can they generate conflict in the classroom but, if not correctly and fully treated, can lead students to assume wrong perspectives and preconceptions about the target culture. From our viewpoint, textbooks should remain neutral regarding controversial topics (e.g. religion 
or politics) and run the risk of being qualified as too rigid and general (Sercu, 2005), or, contrariwise, they should treat them openly by introducing different cultural perspectives.

As abovementioned, institutions and organizations offer the lowest percentages in both textbooks. In EA4, more than a half of the words classified (57.14\%) refer to organizations and NGOs (non-governmental organizations) as in the case MSF (Medicins Sens Frontiers) or UNICEF. There is very little reference to governmental or religious institutions, only two examples were found: Parliament and Catholic Church. Likewise, in AUI 61.54\% of the words refer to an organization or NGOs such as World Wildlife Found (WWF) or Save the Children. As well as in EA4, little or no reference is made to any political (European Parliament) or religious institutions.

As for stereotypes, the results obtained in the study were unexpected. Despite the fact that Siddiqie (2011) and Méndez García (2000) found that there was a tendency of stereotyping in textbooks, we found that stereotypes supposed a small percentage out of the total words classified in our study. Interestingly, the results from EA4 confirm Méndez García's (2000) assertion that some English textbooks tend to represent Spain as a touristic destination. Nevertheless, this stereotype was not present in AUI. Australia as a touristic destination, British bad eating habits and America as a country of international immigrants were found instead. However, given our findings are based only on reading comprehension exercises and vocabulary activities, the results should be treated with caution.

Finally, social interaction is present at different levels in each textbook. There is notable variation regarding the level of the textbook and the situations to which the students are exposed.EA4 provides students with a series of expressions which are included in a "phrase bank" being these phrases useful for different everyday situations (e.g. suggestions, giving news, invitations, and greetings among others). These words and expressions represent the highest results of all in AIU. Nevertheless, unlike EA4, there is not any practice on this new vocabulary in the vast majority of the cases. Most of these words and expressions (73.50\%) are found in little boxes around the units in which the students are given a series of useful expressions for concrete situations (e.g. expressing opinions, describing rights, reacting to information, among others).

As for our second research question (RQ2: How are the different cultures (target, source and international) treated in those textbooks?), there are two categories (cultural heritage and geography) whose results have contributed to determine how each textbook treats different cultures (target, source and international culture). The results evince that there was a great unbalance regarding the proportion in which these three subtypes of culture appear in each textbook. Firstly, both textbooks coincide in the treatment they give to locations related to the target culture as there is little reference to Spanish-speaking countries. From the results, the scarce treatment that the target culture received can be clearly noted.

It should be also stressed the fact that international culture and source culture are treated very differently in both textbooks. AUI seems to show more interest for distinct international cultures and leaves aside places located in the UK. On the contrary, EA4 appears to be more interested in showing information about the UK and pays less attention to international culture.

Similarly, the results in cultural heritage appear to corroborate these different tendencies followed by both textbooks. The analysis of main characters' nationalities shows that 
EA4 follows the same tendency as in geography and just $12.12 \%$ of the characters are not American or British while more than a third are from the US. However, AUI shows a higher percentage regarding famous figures with nationalities different from American or British. Likewise, the fact that both textbooks show a lack of famous or important characters from the Spanish-speaking world indicates that the source culture is ignored in both. These values correlate satisfactorily with Vrbová's (2006), Mahmood, Asghar and Hussain's (2012), Yuen's (2011) and Mendez García's (2000) assertions and further support the idea of the lack of information about the source culture in English textbooks.

There could be several possible explanations for this outcome. Firstly, AUI is an internationally-produced textbook in which the authors are not interested in highlighting a specific culture since it is designed to be used by different students all over the world. On the contrary, although EA4 is a textbook which has been published specifically for ESO (compulsory secondary education) students in Spain, it is again published by a big international publishing house which is not interested in centring the information provided on a specific culture. Secondly, AUI claims to have fully National Geographic content. This magazine is well known by its articles related to geographical, historical and cultural events all over the world. Hence, it should include international cultures that could be linked to these events.

\section{CONCLUSION}

Three main findings stem from the present research study. First, the total number of words related to culture encountered in both textbooks is not balanced. Hence, our data seems to contradict our initial presupposition that higher level textbooks, as is the case of Aspire Upper Intermediate, should contain a higher number of words related to culture.

Our data also indicate that there is a tendency in both textbooks to highlight geographical locations and famous or influent characters, leaving aside controversial topics which can cause tensions in ELT classroom interactions (e.g. politics, socio-politics, economy or religion). This constitutes our second main outcome.

The present study has also confirmed that the ELT textbooks analysed tend to focus on the target culture. This tendency was observed mainly in two of the twelve categories analysed: geography and cultural heritage. However, these two categories also demonstrated a considerable difference regarding the treatment that the source and international cultures received between both textbooks; reinforcing the need of a further analysis.

In the light of the aforementioned outcomes, our research has implications at three levels: education, FLT textbooks publishers and researchers. Concerning education, this paper has provided evidence about the role these two textbooks play to foster students' IC in classroom contexts. This fact concords with the recommendations given by the CEFR (2001), which considers the developing of IC a required skill in language learning. With this in mind, teachers should take into consideration the results when choosing the course textbook. Additionally, they should be aware of the limitations of textbooks and try to complement with other kind of activities which encourage IC. As far as FL textbooks publishers are concerned, this study shed light on those aspects of cultural content in vocabulary which seem to need improvement (e.g. treatment of target and international cultures). Moreover, the study shows that textbooks designers do not follow a specific tendency in IC assessment. 
Some aspects of culture are cleverly treated in one textbook and ignored by the other and vice versa. From this point, it can be concluded that textbook designers should reach a common goal when promoting IC. Finally, as an avenue for further research, there is need to carry out an extensive analysis involving a bigger sample of ELT materials in order to analyse deeply those cases in which the present sample of textbooks have strongly differed from each other (e.g.: cultural heritage).

Further research needs to be conducted in order to establish whether these differences are due to the distinct levels of both textbooks or, in contrast, it is a constant even in books of the same level. Furthermore, future studies may include the other skills and sections contained in textbooks (e.g. listening, grammar and writing activities) in order to determine if this affects somehow the results obtained in the reading and vocabulary tasks.

\section{REFERENCES}

Bennett, T., Grossberg, L. and M. Morris. 2005. New Keywords: a Revised Vocabulary of Culture. Malden: Blackwell Pub.

Byram, M. 1989. Cultural Studies in Foreign Language Education. Clevedon: Multilingual Matters.

1997. Teaching and Assessing Intercultural Communicative Competence. Clevedon: Multilingual Matters.

Byram, M. and C. Morgan. 1994. Teaching-and-Learning Language-and-Culture. Clevedon: Multilingual Matters.

Byram, M. and K., Risager. 1999. Language Teachers, Politics and Cultures. Clevedon: Multilingual Matters.

Byram, M. and M. Fleming. 1998. Language Learning in Intercultural Perspective. Cambridge: Cambridge University Press.

Byram, M. and V. Esarte-SARries. (1991). Investigating Cultural Studies in Foreign Language Teaching. Clevedon: Multilingual Matters.

CORTAZZI, M. and L. JiN. 1999. "Cultural mirrors: Materials and methods in EFL classroom”. Culture in Second Language Teaching. Ed. E. Hinkel Cambridge: Cambridge University Press. 196-219.

Common European Framework of Reference for Language. Learning, Teaching and Assessment. 2001. Cambridge: Cambridge University Press.

CRIADO, R. 2009. "The distribution of the lexical component in ELT coursebooks and its suitability for vocabulary acquisition from a cognitive perspective. A case study". International Journal of English Studies 9, 3: 39-60.

Criado, R. and A. SÁnchez. 2012. "Lexical frequency, textbooks and learning from a cognitive perspective. A corpus-based sample analysis of ELT materials". RESLA Extra, 1: 77-94. 
DeardorfF, D. K. 2006. "Identification and assessment of intercultural competence as a student outcome of internationalization". Journal of Studies in International Education 10, 3: 241-266.

Dimitrijevic, N.R. 1977. "Problems and implications of contrastive analysis of vocabulary and culture”. Poznan Studies in Contemporary Linguistics 7: 133-144.

Dummett, P., Benne, R. R. and R. Crossley. 2012 . Aspire Upper-Intermediate. China: Heinle.

Georgievska, E. 2000. "Textbook vocabulary and cultural competence: A Case Study in EFL in the Republic of Macedonia. Durham theses, Durham University. 30 Jan. 2015. http://etheses.dur.ac.uk/4532/

HamiloĞLu, K. and B. Mendi. 2010. "A content analysis related to the cross-cultural/ intercultural elements used in EFL coursebooks”. Sino-US English Teaching 7, 1: $16-24$

Hu, M. and P. NATiOn. 2000 . "Vocabulary density and reading comprehension". Reading in a Foreign Language 13: 403-430.

Jimenez Catalan, R. and R. Mancebo Francisco. 2008. "Vocabulary input in EFL textbooks". RESLA 21: 147-165.

Jiménez, R. T., García, G. E., and P. D. Pearson. 1996. "The reading strategies of bilingual Latina/o students who are successful English readers: Opportunities and obstacles". Reading Research Quarterly 31: 90-112.

Kramsch, C. 1993. Context and Culture in Language Teaching. Oxford: Oxford University Press.

LidDICOAT, A. and A. SCARINO. 2013. Intercultural Language Teaching and Learning. Malaysia: Willey-Blackwell.

Mahmood M. A., Asghar, A. M. and Z. Hussain. 2012. "Cultural Representation in ESL Textbooks in Pakistan: A Case Study of "Step Ahead 1". Journal of Education and Practice 3, 9: 35-42.

Méndez García, M. 2000. La Competencia cultural en la enseñanza del inglés como lengua extranjera: supuestos teóricos, análisis de su tratamiento en una muestra de libros de texto de inglés de bachillerato y propuesta de un currículum sociocultural. $\mathrm{PhD}$ thesis. University of Jaen. Spain. 30 Sept. 2014. http://hdl.handle.net/10953/396.

NAGY, W. 1997. "On the role of context in first-and second-language vocabulary learning”. Vocabulary: Description, Acquisition, and Pedagogy. Eds. N. Sснмiтt and M. McCARthy. New York: Cambridge University Press. 64-83.

Paricio TAto, M. S. 2014. "Competencia intercultural en la enseñanza de lenguas extranjeras". Porta Linguarum 21:215-226. 15 Oct. 2014.http://www.ugr.es/ portalin/ articulos/PL_numero21/14\%20\%20Silvina.pdf.

Pingel, F. 2010. UNESCO Guidebook on Textbook Research and Textbook Revision. Poppdruck: Langenhagen. 
RisAGER, K. 1990. "Cultural references in European textbooks: An evaluation of recent tendencies". Mediating Languages and Cultures. Eds. D. Buttues and M. B yram. Clevedon: Multicultural Matters. 181-193.

SerCu, L. 2005. Foreign Language Teachers and Intercultural Competence: An International Investigation. Cromwell: Multilingual Matters.

SiddiQIE, S. A. 2011. "Intercultural exposure through English language teaching: An analysis of an English language textbook in Bangladesh". Journal of Pan-pacific Association of Applied Linguistics 15, 2: 109-127.

TAs, S. 2010. "A critical evaluation of New English File Series in Terms of culture teaching". Ordu University. 26 Nov. 2014. http://sobiad.odu.edu.tr/files/cilt1/cil1sayi2_pdf/tas_seda.pdf.

Verhoeven, L. T. 1990. "Acquisition of reading in a second language". Reading Research Quarterly 25: 90-114.

Vrbová, L. 2006. Developing Cultural Awareness in ELT. Master thesis. University of Pardubice. Czech Republic. 1 Oct. 2014. https://dspace.upce.cz/bitstream/10195/24021/1/D14985.pdf.

Wetz, B. 2008. English Alive 4. Oxford: Oxford University Press.

WiERzBickA, A. 1997. Understanding Cultures through their Key Words. Oxford: Oxford University Press.

WiLliams, R. 1976. Keywords: a Vocabulary of Culture and Society. New York: Oxford University Press.

Wu, J. 2010. "A content analysis of the cultural content in the EFL textbooks". Canadian Social Science 6, 5: 137-144.

YuEN, K. M. 2011. "The representation of foreign cultures in English textbooks". ELT Journal 65, 4: 458-466. Accessed 10 Oct. 2014. http://eltj.oxfordjournals.org/ content/65/4/458.full.pdf+html. 